\begin{tabular}{|c|c|c|}
\hline $\begin{array}{l}\text { 2. To: (Receiving Organization) } \\
\text { Distribution }\end{array}$ & $\begin{array}{l}\text { 3. From: (originating Organization) } \\
\text { TFRSO }\end{array}$ & $\begin{array}{r}\text { 4. Related EDT No.: } \\
\text { N/A }\end{array}$ \\
\hline $\begin{array}{l}\text { 5. Proj./Prog./Dept./Div.: } \\
\text { W-314/TWRS }\end{array}$ & $\begin{array}{l}\text { 6. Design Authority/ Design Agent/Cog. } \\
\text { Engr.: } \\
\text { D.E. Bowers }\end{array}$ & $\begin{array}{r}\text { 7. Purchase order No.: } \\
\qquad N / A\end{array}$ \\
\hline \multirow{2}{*}{\multicolumn{2}{|c|}{$\begin{array}{l}\text { 8. Originator Remarks: } \\
\text { This EDT release the approved ATP's for the } 241-A N-A \text { and } B \\
\text { packages part of Project } W-314 \text {. }\end{array}$}} & $\begin{array}{r}\text { 9. Equip./Component No.: } \\
N / A\end{array}$ \\
\hline & & $\begin{array}{c}\text { 10. System/8ldg./Facility: } \\
\text { N/A }\end{array}$ \\
\hline \multirow{3}{*}{\multicolumn{2}{|c|}{ 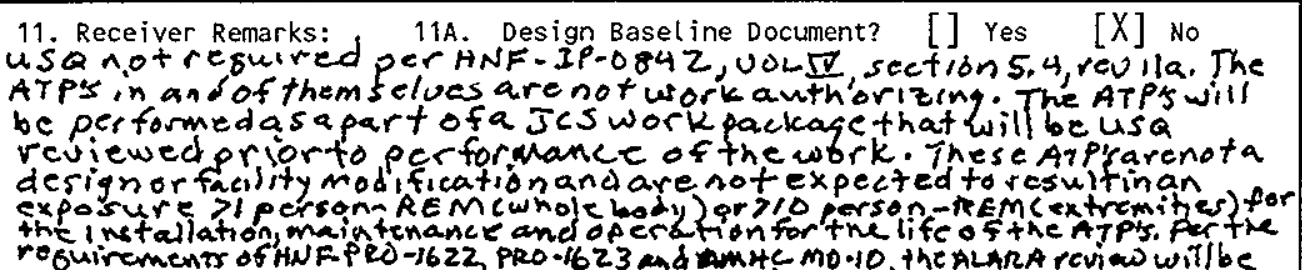 }} & $\begin{array}{l}\text { 12. Major Assm. Dwg. No.: } \\
\text { N/A }\end{array}$ \\
\hline & & $\begin{array}{l}\text { 13. Permit/Permit Application No.: } \\
\text { N/A }\end{array}$ \\
\hline & & $\begin{array}{l}\text { 14. Required Response Date: } \\
\text { N/A }\end{array}$ \\
\hline
\end{tabular}

accomplishedas partof the normalkadiolegical work planning process. 0 SB5.27-99

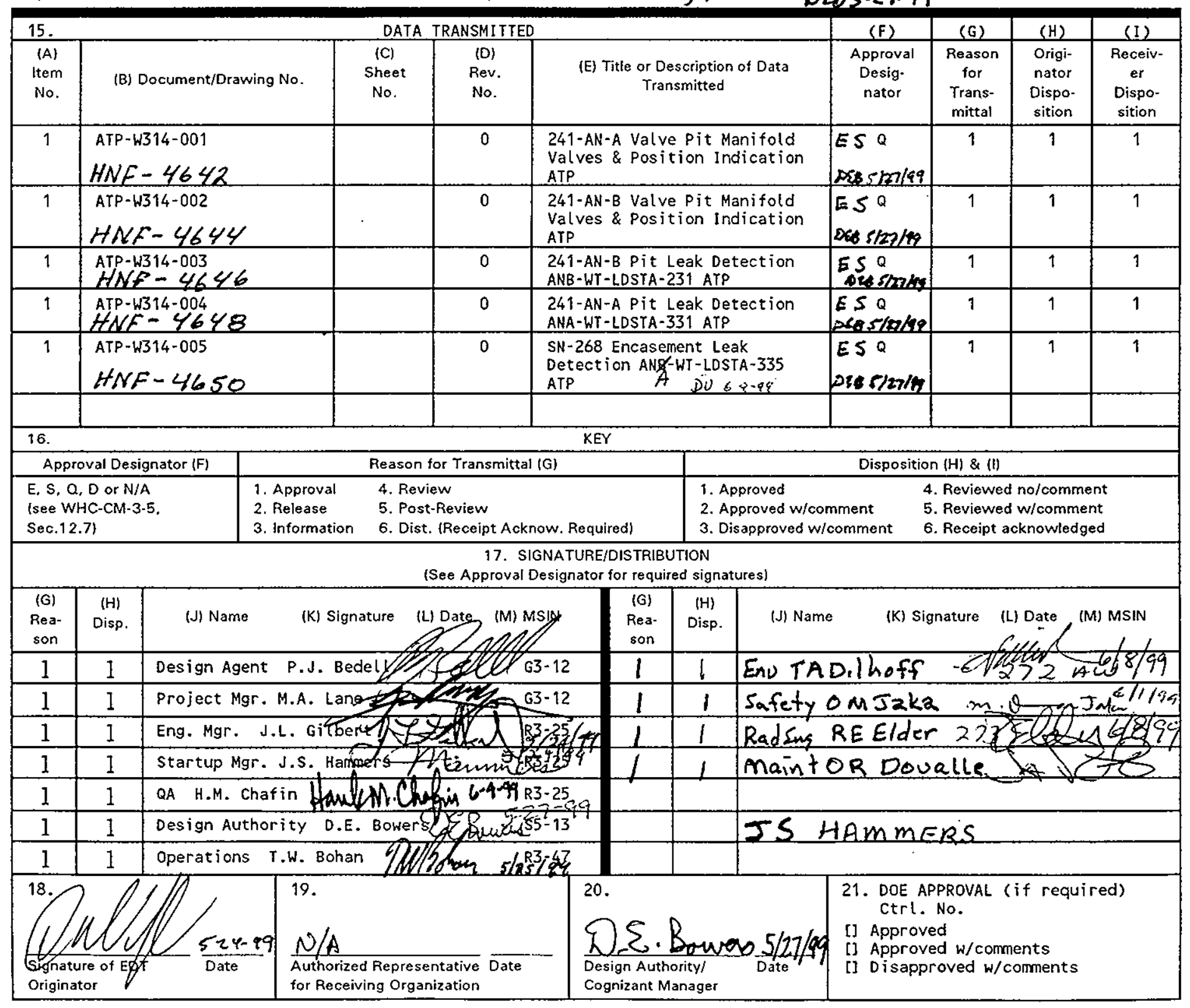


HNF-4650, Rev. 0

\section{SN-268 Encasement Leak Detection ANA-WT-LDSTA-335 Acceptance Test Procedure}

David พ. VanDyke

Maintenance Concepts

Richland, WA 99352

U.S. Department of Energy Contract DE-AC06-96RL13200

EDT/ECN: 626838

Org Code: LJH20000

B\&R Code: EW3130010
UC: 2030

Charge Code: 106065

Total Pages: 44

Key Words: Acceptance Test Procedure

Abstract: This document describes the method used to test design criteria for encasement leak detector system installed in 241-AN-A Encasement Line SN-268, located at 200E Tank Farms.

TRADEMARK DISCLAIMER. Reference herein to any specific commercial product, process, or service by trade name, trademark, manufacturer, or otherwise, does not necessarily constitute or imply its endorsement, recommendation, or favoring by the United States Government or any agency thereof or its contractors or subcontractors.

Printed in the United States of America. To obtain copies of this document, contact: Document Control Services, P.O. Box 950, Mailstop H6-08, Richland WA 99352, Phone (509) 372-2420; Fax (509) 376-4989.

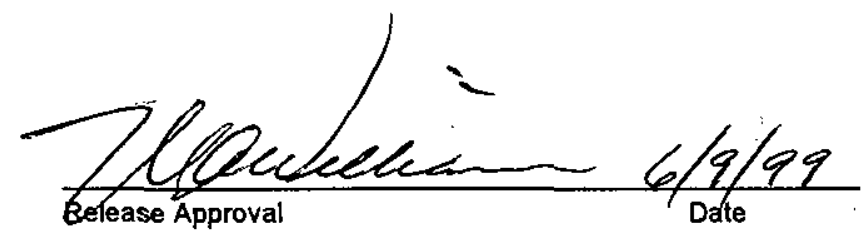

Approved For Public Release 

ACCEPTANCE TEST PROCEDURE

\begin{tabular}{|c|c|c|c|c|}
\hline Wor & 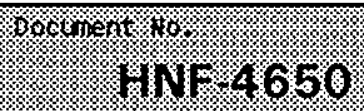 & \% & W y s w & 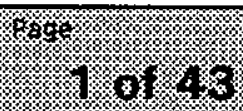 \\
\hline
\end{tabular}




\section{TABLE OF CONTENTS}

TEST EXECUTION SHEET ............................ 3

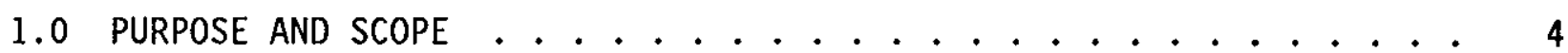

1.1 PURPOSE .............................. 4

1.2 SCOPE ........................ 4

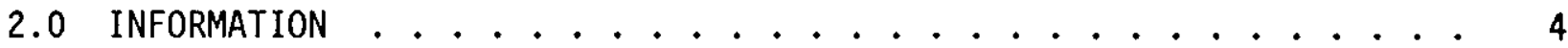

2.1 TERMS AND DEFINITIONS .................. 4

2.2 RESPONSIBILITIES . . . . . . . . . . . . . 4

2.3 RECORDS .................... . . . 9

2.4 REFERENCES ................... . . . 9

2.5 GENERAL INFORMATION . . . . . . . . . . . 10

3.0 PRECAUTIONS AND LIMITATIONS . . . . . . . . . . . . . . . 14

3.1 PERSONNEL SAFETY ................ 14

3.2 RADIATION AND CONTAMINATION CONTROL ........... 14

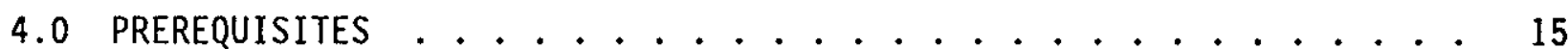

4.1 SPECIAL TOOLS, EQUIPMENT, AND SUPPLIES $\ldots \ldots$

4.2 PERFORMANCE DOCUMENTS ................ 15

4.3 CONDITIONS AND ACTIONS .................... 16

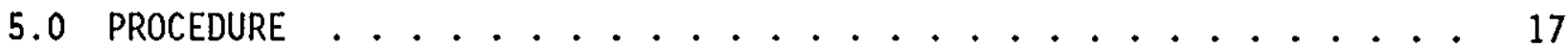

5.1 POWER REQUIREMENTS TEST . . . . . . . . . . . 17

5.2 SETTING THE MTL TRIP AMPLIFIER ............ 19

5.3 B/W LEAK DETECTION RELAY SWITCH TEST . . . . . . . . . . 22

5.4 LAMP TEST . . . . . . . . . . . . . . . 24

5.5 B/W LEAK DETECTION RELAY LEAK SIMULATION TEST . . . . . . . . 25

5.6 MTL FAIL SAFE RELAY SWITCH TEST . . . . . . . . . . 28

5.7 MTL FAIL SAFE RELAY SIMULATION TEST . . . . . . . . . 30

5.8 REMOTE RESET TEST . . . . . . . . . . . . . . 33

5.9 REMOTE TRIP AMPLIFIER $\backslash$ VOLTAGE RELAY TEST $\ldots . . . . . . .35$

5.10 REMOTE LEAK DETECTION RELAY TEST. . . . . . . . . . . 37

ATP PERFORMANCE LOG ...................... 39

ATP EXCEPTION LOG ...................... . . 40

ATP EXCEPTION RECORD ..................... 41

PROCEDURE SIGNATURE SHEET .................. 42

PROCEDURE HISTORY SIGNATURE SHEET . . . . . . . . . . . 43

\begin{tabular}{|c|c|c|c|c|}
\hline CONMNUIOS & 7. & $2=0$ & (20) & fis: \\
\hline
\end{tabular}




\section{TEST EXECUTION SHEET}

\begin{tabular}{|c|c|}
\hline Date: & Document Nǘser?: \\
\hline \multicolumn{2}{|c|}{ 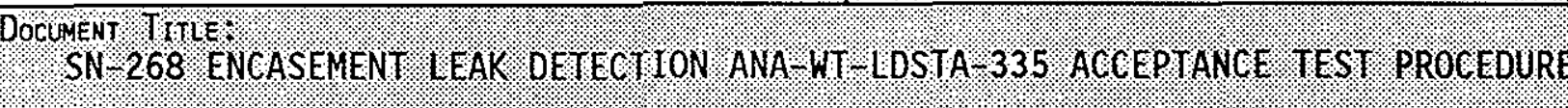 } \\
\hline \multicolumn{2}{|c|}{ TEST PERSONNEI (PRINT NAMES) } \\
\hline TEST DiReCtor: & AUTHORIZED INSPECTOR: \\
\hline OPERATIONS ENGINEer: & RECORDER: \\
\hline \multicolumn{2}{|c|}{ TEST EXECUTION } \\
\hline Test Director Signature/Date: & $\begin{array}{l}\text { Fluor Daniel Northuest } \\
\text { Construction Engineer: Signature/Date: }\end{array}$ \\
\hline Operations Engineer Signature/Date: & Recorder Signature/Date: \\
\hline \multicolumn{2}{|c|}{ APPROVAL AND ACCEPTANCE OF TEST RESUITS } \\
\hline $\begin{array}{c}\text { WITHOUT EXCEPIION } \\
(J)\end{array}$ & $\begin{array}{l}\text { Resolved With Exceptions Remaining } \\
\text { ( })\end{array}$ \\
\hline Test Director Signature/Date: & W-314 Project Manager Signature/Date: \\
\hline $\begin{array}{l}\text { Fluor Daniel Northuest Project Manager } \\
\text { Signature/Date: }\end{array}$ & FDNW Quality Assurance Signature/Date: \\
\hline LMHC Quality Assurance Signature/Date: & Operations Engineer Signature/Date: \\
\hline AUTHORIZED InSPECTOR SignatURe/Date: & Design Authority Signature/Date: \\
\hline
\end{tabular}




\subsection{PURPOSE AND SCOPE}

\subsection{PURPOSE}

This procedure provides instructions for demonstrating that the pit leak detection relay cabinet and intrinsically safe probe circuit is fully operable.

\subsection{SCOPE}

This Acceptance Test Procedure will test all functions of the ANA-WT-LDSTA-335 encasement leak detection relay cabinet and associated components.

\subsection{INFORMATION}

\subsection{TERMS AND DEFINITIONS}
2.1.1 ATR -
Acceptance Test Report
2.1.2 ATP -
Acceptance Test Procedure

\subsection{RESPONSIBILITIES}

2.2.1 Each company or organization participating in the conduct of this procedure will designate personnel to assume the responsibilities and duties as defined herein for their respective roles. The names of these designees shall be provided to the Recorder for listing on the Working Copy of the Test Execution Sheet prior to the performance of any part of this procedure.

2.2.2 The Fluor Daniel Northwest Project Manager is responsible for the following:

- Designation of a test director

- Signing the Test Execution Sheet when the Acceptance Test Procedure is approved and accepted as complete.

2.2.3 The Operations Engineer is responsible for the following:

- Setting the safe boundaries for performing this procedure

- Ensuring plant configuration is in proper status for performing this procedure 


\subsection{RESPONSIBILITIES (cont.)}

- Signing for operations where applicable in this procedure

- Performing a Post-Test Review of Acceptance Test documentation

- Obtaining concurrence from Tank Farm Shift Manager prior to commencing the test, or upon restart of testing after a temporary suspension of testing.

2.2.4 The Operations Representative is responsible for the following:

- Ensuring that safe work boundaries for testing are complied with

- Coordinating all support craft and personnel in field with the Test Director and the Construction Engineer.

- Obtaining release of this ATP for field testing from shift office.

2.2.5 The Test Director is responsible for the following:

- Coordination of all acceptance testing

- $\quad$ Signing the ATP Exception Record when a test exception has been resolved

- Preparing and issuing an Acceptance Test Report for the approved and accepted Acceptance Test Procedure when testing is completed

- Scheduling and conducting a pre-test meeting with acceptance test participants prior to start of testing

- Notification of the persons performing and witnessing the test prior to the start of testing

\begin{tabular}{|c|c|c|c|c|}
\hline \% & r: & : & 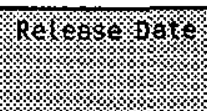 & 14. \\
\hline
\end{tabular}




\subsection{RESPONSIBILITIES (cont.)}

- Notification of all concerned parties when a change is made in the testing schedule

- Acting as 1iaison between the participants in acceptance testing

- Stopping any test which may cause damage to the system unti1 the Acceptance Test Procedure has been revised.

- Approving field changes to the Acceptance Test Procedure in accordance with Section 2.5.

- Obtaining revisions to the Acceptance Test Procedure, as necessary, to comply with authorized field changes or to accommodate existing field conditions in accordance with Section 2.5 .

- Taking necessary actions to clear exceptions to the Acceptance Test Procedure

- Evaluating recorded data, discrepancies, and exceptions

- $\quad$ Signing Test Execution Sheet when this Acceptance Test Procedure has been performed

- Signing ATP Exception Record when a retest to clear an exception has been executed and accepted

- Obtaining required signatures on the Acceptance Test Procedure Working Copy prior to reproduction and distribution

2.2.6 The Recorder is responsible for the following:

- Performing all recording duties using black ink

- Recording the names of all designated personnel on the Working Copy of this procedure prior to start of testing

- Observing tests, recording test data, and maintaining the ATP Performance Log

\begin{tabular}{|c|c|c|c|c|}
\hline \% & \% & 4 & 3. & 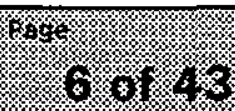 \\
\hline
\end{tabular}




\subsection{RESPONSIBILITIES (cont.)}

- Signing the Test Execution Sheet as the Recorder

- Initialing every test verification step requiring initials on the Working Copy of this Acceptance Test Procedure as that step is successfully performed, to indicate that Acceptance Criterion has been met

- Recording authorized field changes to this Acceptance Test Procedure

- Recording Test Exceptions and individuat Test Procedure steps that are not performed satisfactorily on the ATP Exception Record and ensuring that the information is transferred (in ink or typed) to the master Working Copy of ATP Exception Record(s). Additional ATP Exception Records are to be added as needed

- Notifying the Test Director at the time any objection is made during performance of the Acceptance Test Procedure

- Submitting the completed master Working Copy of this Acceptance Test Procedure to the Test Director for approval signatures and distribution.

2.2.7 The Construction Engineer is responsible for the following:

- Ensuring al1 equipment required for performing this Acceptance Test Procedure 1isted in Section 4.1 will be available at the start of testing

- Obtaining from the NHC and LMHC Project Engineer any information or changes necessary to clear or resolve objections

- Coordinating field personnel and activities with the Test Director and Operations Representative

- Ensuring that field testing and inspection of the system or portion of the system to be tested has been completed

- Providing technical input to test personnel as needed relating to the configuration of equipment and systems to be tested and utilized in this procedure.

- Post Review of Acceptance Test Documentation.

\begin{tabular}{|c|c|c|c|c|}
\hline 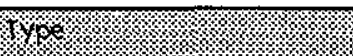 & 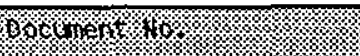 & 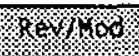 & 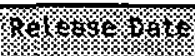 & 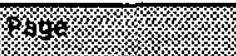 \\
\hline OOH W & mint 4650 & O & & \\
\hline
\end{tabular}


·aunpazoud s!̣\} u! әlqeว! Ldde se saว!^ap

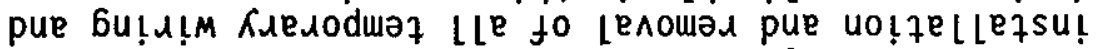

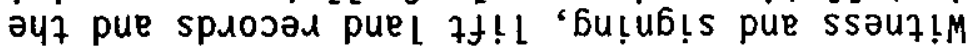

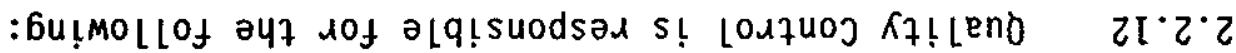

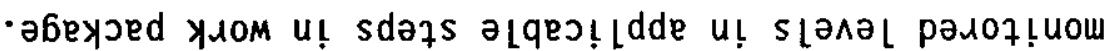

Gu!projad pue e! Le! 17 Snpu! 1ә470 10 200-dSH-WM-OS-JNH of 6u!puosore

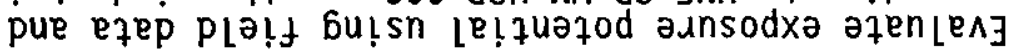

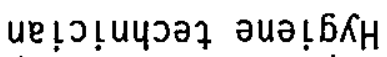

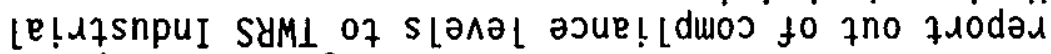
pue sioden 10 sase6 alq!7snquos pue $2 ! \times 07$ lof 107 !luow

:6utmollof

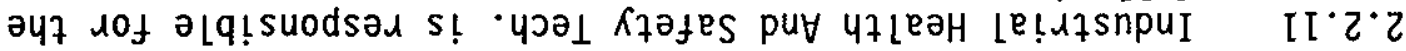

- כunposoud s!yz to

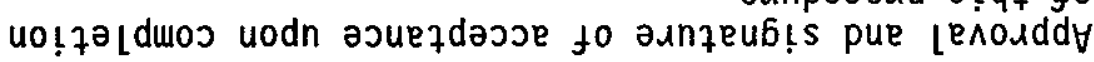

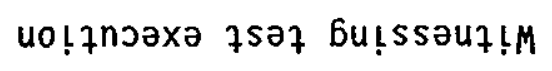

:6u!MOLLOS әY7 105

alq!suodsad s! dozoədsuI paz!doyzny profueH la! ueg donlf

OI $\cdot 2 \cdot 2$

uo!fequaunjop

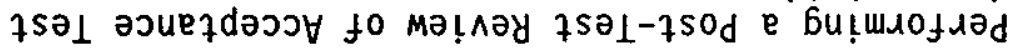

sflnsad zsaz to Lenoudde pue mə!̣ıәy

: butmollof

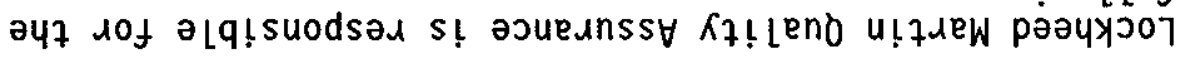

$6 \cdot 2 \cdot 2$

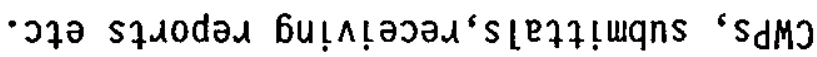

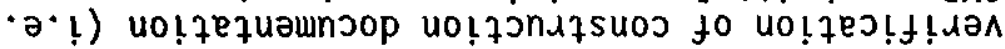

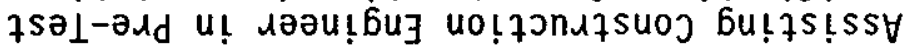

uo! fequamnoop

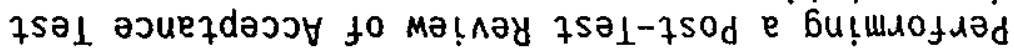

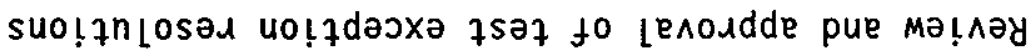

: 6 u!mollof ayz lof

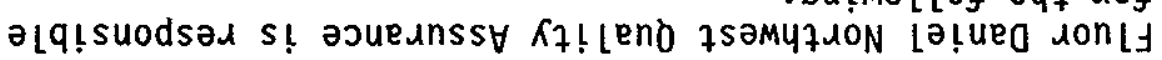

$8 \cdot 2 \cdot 2$

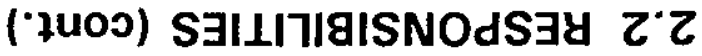




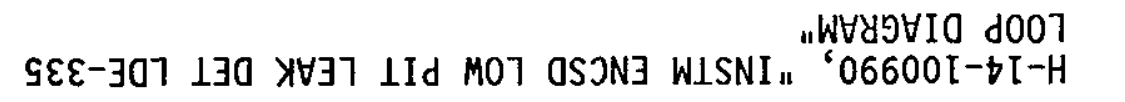
$\exists \Lambda 7 \forall \wedge$ ᄉาgW "WVYפYIO NOI13JNNOJYJINI XOg 7VNIWY $107 \exists I \unlhd$ WLSNI" "88600I-๖I-H

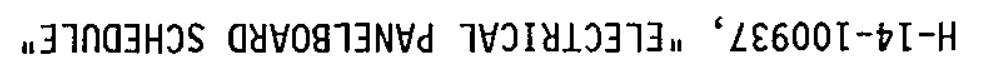

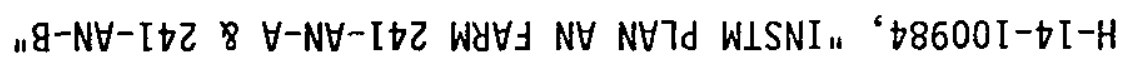

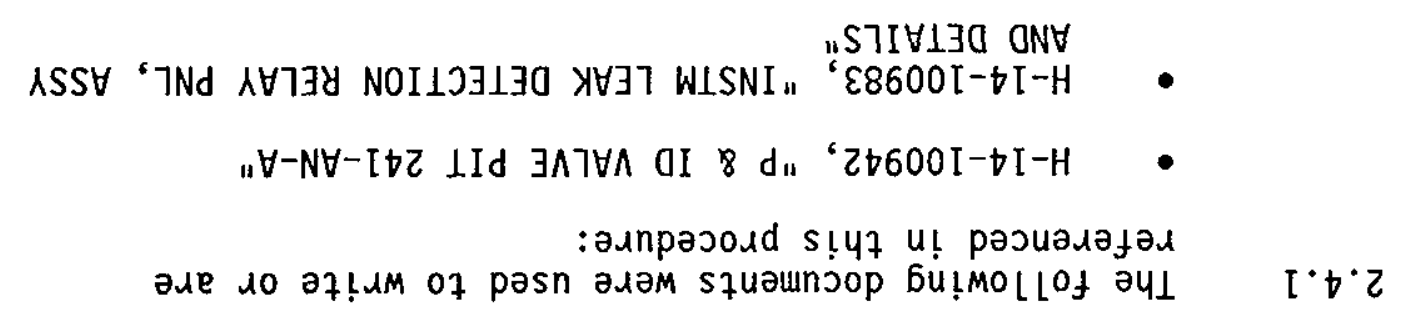

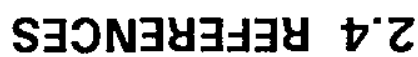

- sprojar quauemuəd se 7 dar aq LL!M aגnpajosd

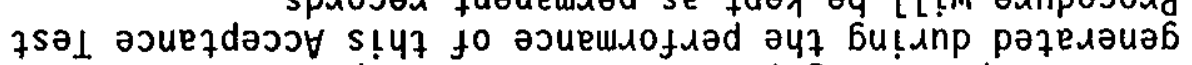

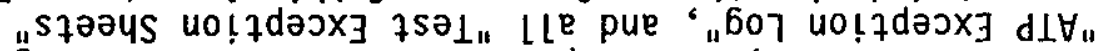

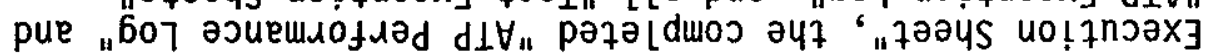

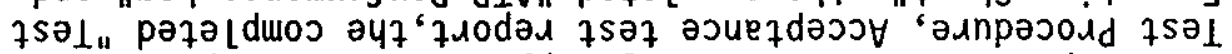

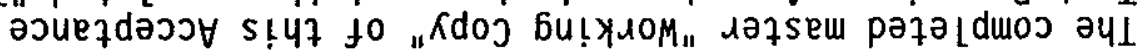




\subsection{GENERAL INFORMATION}

2.5.1 Al1 steps in this Acceptance Test Procedure are performed at the 24I-AN-A Valve Pit, unless otherwise noted.

2.5.2 ACCEPTANCE CRITERIA: A1] Test Procedure steps using the word VERIFY are considered Acceptance Criteria steps, and each must have successful execution indicated by having initials and the date entered in the provided space to be considered complete.

2.5.3 All entries recorded in this procedure shall be made in black ink, except for those noted using the redline method.

2.5.4 Required editorial changes to this procedure may be made by the Test Director and Cognizant Engineer per HNF-IP-0842, "Technical Procedure Requirements", as long as the changes do not impact operational facility safety function or performance, and will not compromise or influence the test data. Any technical change must be made by $\mathrm{ECN}$.

2.5.5 Acceptance Test steps detailed in individual Test Procedures in Section 5.0 shall be performed sequentially, unless otherwise noted or as directed by the Test

Director.

- Individual Test Procedures may be performed out of sequence at the direction of the Test Director, if the intent of the test is not compromised

- As required by Step 2.2.6, as each step is completed, the Recorder will check off or initial each Test step as required in the spaces provided on the Working Copy of this Acceptance Test Procedure

- Any step that requires verification of data must also include recording data on the Working Copy. 


\subsection{GENERAL INFORMATION (Cont.)}

2.5.6 It is the intent to perform this Acceptance Test Procedure uninterrupted from beginning to end. If testing is terminated due to time constraints at the end of an individual Test Procedure, the system will be placed in a safe configuration by the Test Director, with concurrence of the Operations Engineer, and the terminated test configuration noted in the ATP Performance Log. The test will restart at the next scheduled shift by establishing the noted test configuration, and documenting this on ATP Performance Log.

2.5.7 Any non-conformance of the instrumentation, unexpected results or exceptions during testing shall be sequentially numbered and recorded in the ATP Exception Log and on individual ATP Exception Records. Thus, case-by-case resolution, recording, approval, and distribution of each exception will be achieved.

2.5.8 When an exception is identified during testing, initiate an ATP Exception Record in the following manner

- Number each exception sequentially as it occurs and record it on the ATP Exception Log

- Enter the sequential exception number, Date, and a description of the exception on an ATP Exception Record; identify additional detail as required

- Enter the name and/or the organization of the objecting party for each exception in the "Description of Exception" section of the ATP Exception Record

- Enter a description of actions planned to resolve each exception on the ATP Exception Record when such a determination is made. 


\subsection{GENERAL INFORMATION (Cont.)}

2.5.9 Resolve test exceptions in the following manner:

- Record the action taken to resolve each exception in the "Resolution of Exception" section of the ATP Exception Record (the action taken does not have to be the same as the recorded planned action)

- When the action taken results in an acceptable retest, initial and date the Correction Approval section of the Exception Sheet

- When the action taken does not result in an acceptable retest, provide a detailed explanation of why the retest action was not acceptable, and what additional plans are required. The explanation may include why the system should be Accepted-As-Is. The NHC Project Engineer then signs and dates the Resolution of Exception section of the ATP Exception Record, and obtains any other approvals required

- Distribute requisite copies of the completed ATP Exception Records to the client at the completion of the Acceptance Test Procedure.

2.5.10 Upon completion of the Acceptance Test Procedure, obtain approval of the test performance. The Acceptance Test will be complete when all the outstanding tests have been performed and the Acceptance Test Report is prepared. The test will be approved by checking the proper response, with or without exceptions, on the Test Execution Sheet under the "Approval and Acceptance of Test Results" section of the Test Execution Sheet. 


\subsection{GENERAL INFORMATION (Cont.)}

NOTE - The following three steps detail the possible conditions that may exist at the completion of the Acceptance Test Procedure, and the steps necessary to complete Procedure acceptance in those conditions.

2.5.11 The completed test may be approved without test exceptions:

- Check applicable space on Test Execution Sheet to show that the Acceptance Test Procedure has been performed and no exceptions have been recorded

- Appropriate individual Test Performers will sign and date the Test Execution Sheet in the spaces provided

- Distribute requisite copies as directed by the client

- Send the Master Copy of the completed Acceptance Test Procedure to the client.

2.5.12 The completed test may be approved with exceptions resolved:

- Check applicable space on Test Execution Sheet to show that this procedure has been performed with exceptions recorded and resolved

- Appropriate individual Test Performers will sign and date the Test Execution Sheet in the spaces provided

- Distribute requisite copies as directed by the client

- Send the Master Copy of the completed Acceptance Test Procedure to the client.

2.5.13 The completed test may be approved with test exceptions outstanding:

- Check applicable space on Test Execution Sheet to show that this procedure has been performed with exceptions recorded, part or all of which are presently outstanding, unresolved

- Appropriate individual Test Performers will sign and date the Test Execution Sheet in the spaces provided

- Distribute requisite copies as directed by the client

- Send the Master Copy of the completed Acceptance Test Procedure to the client

- All outstanding exceptions shatl be added to project punchlist. 


\subsection{PRECAUTIONS AND LIMITATIONS}

\subsection{PERSONNEL SAFETY}

3.1.1 Individuals shall carry out their assigned work in a safe manner to protect themselves, others, and the equipment from undue hazards and to prevent damage to property and environment.

3.1.2 Operations Representative shall assure the safety of all activities within their areas to prevent injury, property damage, or interruption of operation.

3.1.3 Any hazard identified during the performance of the procedure shall be reported to the operations Representative and the Test Director.

3.1.4 A daily pre-job safety briefing will be held with all test participants and documented in the ATP Performance Log.

3.1.5 Performance of test activities shall always include safety and health aspects as del ineated in the Operations Manuals and as directed by the Test Director.

3.1.6 An Energized Work Permit will be needed for performance of this procedure.

\subsection{RADIATION AND CONTAMINATION CONTROL}

Work in Radiological Areas will be performed using an approved Radiation Work Permit, following review by Radiological Control per the ALARA Program (HNF-IP-0842, Volume VII, Section 1.I). 
4.0 PREREQUISITES

\subsection{SPECIAL TOOLS, EQUIPMENT, AND SUPPLIES}

The following supplies shall be available at the test site:

- Electrician protective gloves

- Electrician protective eyewear (goggles or face shield)

- Calibrated Volt Ohm Meter (Fluke)

- Long-shank lockout padlock

- Ruler, with minimum scale markings of $1 / 16$ inch

- Fuse Puller

- Torquing Screwdriver (17-20 inch 1bs)

- 24 volt dc Power Supply.

- $\quad 0-10$ volt adjustable voltage source

- Variable voltage source $0-5$ VDC $\pm 5 \%$

- $\quad$ Single pole, single throw switch rated (minimum) 5 amp 120 $\mathrm{Vac}$

- 10 Gallon container (minimum) for water with ability to regulate flow out of container to (1 Gal/Hr).

NOTE - Calibrated electrical test equipment data shall be recorded at the beginning of each individual test section.

\subsection{PERFORMANCE DOCUMENTS}

The following procedures may be needed to perform this procedure:

- As-Built Drawings 


\subsection{CONDITIONS AND ACTIONS}

The following conditions must be met before this Acceptance Test Procedure (ATP) may commence:

NOTE- $\quad$ A jumper has been installed preventing Master Pump Shut down. This jumper shall be part of the inspection of system to be tested.

NOTE- All signators on this procedure shall document their signature on Procedure Signature Sheet.

4.3.1 Al1 field testing and inspection of the system or portions of the system to be tested has been completed

$$
\text { Construction Engineer Signature } \longdiv { \text { Date } }
$$

4.3.2 A pre-job briefing has been held. and all participants have been thoroughly briefed on job safety, hazards, and their responsibilities before performing this ATP.
Test Director Signature
Date

4.3.3 VERIFY 241-AN-A Valve Pit is isolated from all other transfer routes.

Test Director Signature $\longrightarrow$ Date

4.3.4 VERIFY with Shift Manager NO transfers are occurring or planned during the performance of the test.

Test Director Signature $\longrightarrow$ Date

4.3.5 VERIFY IH\&S Tech. has performed monitoring of pit and signed in applicable sections of work package.

Test Director Signature Date

4.3.6 Test Director VERIFY section 4.0 has been COMPLETED.

Test Director Signature Date

\begin{tabular}{|c|c|c|c|c|}
\hline \%or & . & (3. & 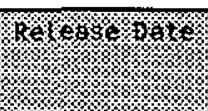 & (4.9.4. \\
\hline
\end{tabular}




\subsection{PROCEDURE}

NOTE - These tests may require certain individuals to carry and operate hand held communication devices. This is necessary for communications from the AN Tank Farm testing area to the AN241-AN-271 building while generating alarms.

\subsection{POWER REQUIREMENTS TEST}

ELECTRICAL TEST EQUIPMENT DATA TABLE

\begin{tabular}{|l|l|l|l|}
\hline TOOL NAME & ID. NUMBER & CAL DUE DATE & INITIAL/DATE \\
\hline & & & \\
\hline & & & \\
\hline & & & \\
\hline
\end{tabular}

CIRCUIT BREAKER RATINGS

5.1.1 LOCATE AND VERIFY 120 Vac circuit breaker, circuit No. 29 in paneTboard EDS-DP-105 has a trip rating of 20 Amps. (Reference Drawing $\mathrm{H}-14-100937$, ELECTRICAL PANELBOARD SCHEDULE").

$$
\overline{\text { Test Director Initial }}
$$

VOLTAGE VERIFICATION

5.1.2 REMOVE cover of electrical panelboard EDS-DP-105.

NOTE - Voltage in the following step should be between 114 to 126 volts.

5.1.3 MEASURE AND RECORD, using a volt/ohm meter, the main bus voltage from phase $A$ to ground.

VOLTAGE

5.1.4 MEASURE AND RECORD, using a volt/ohm meter, the main bus voltage from phase $B$ to ground.

VOLTAGE

5.1.5 ENSURE circuit breaker 29 in Panelboard EDS-DP-105 is in the CLOSED or ON position. 


\subsection{POWER REQUIREMENTS TEST (Cont.)}

NOTE - Voltage in the following step should be BETWEEN 114 to 126 volts.

5.1.6 MEASURE AND RECORD load side voltage of circuit No. 29 to ground.

VOLTAGE

5.1.7 IF voltage is NOT within the 114-126 volt range THEN IDENTIFY AND CORRECT voltage deficiency, AND REPEAT Step 5.1 .6 .

5.1.8 REPLACE cover of electrical paneTboard EDS-DP-105.

5.1.9 ENSURE paneT ANA-WT-LDSTA-335 disconnect switch ANA-WT-DS-335 is in the OPEN or OFF position, AND local strobe light alarm is deactivated.

Note - Voltage should be BETWEEN 114 and 126 volts. It may be necessary to remove the line shield Item No. 39, drawing H-14-100983, attached to the disconnect switch Item No. 35 , drawing $H-14-100983$, to verify voltages. Disconnect power to the leak detection relay cabinet, circuit No.29 panelboard EDS-DP-105, before attempting to remove the disconnect line shield. If the line voltage does not fall BETWEEN the above voltage range, identify and correct the wiring deficiency to ANA-WT-LDSTA-335.

5.1.10 MEASURE AND RECORD voltage supplied to panel

ANA-WT-LDSTA-335.

VOLTAGE

5.1.11 REPLACE line shield removed on previous step, if necessary.

5.1.12 ENSURE disconnect switch ANA-WT-DS-335 for ANA-WT-LDSTA-335 is left in the CLOSED or ON position.

5.1.13 VERIFY Test 5.1 is COMPLETE by.

Test Director Signature

Operations Signature

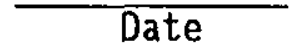

Date 


\subsection{SETTING THE MTL TRIP AMPLIFIER}

5.2.1 VERIFY IH\&S Tech, has monitored pit prior to performing this section.

\section{Test Director Initial}

NOTE - The following set-up must be completed before further testing. The MTL Trip Amplifier (Item No. 22, Drawing No. H-14-100983) must be set prior to testing the leak detection relay cabinet assembly.

ELECTRICAL TEST EQUIPMENT DATA TABLE

\begin{tabular}{|c|c|c|c|}
\hline TOOL NAME & 1D. NUMBER & CAL OUUE DATE & SMT LAL DATE \\
\hline & & & \\
\hline & & & \\
\hline & & & \\
\hline
\end{tabular}

5.2.2 DEENERGIZE leak detection relay panel ANA-WT-LDSTA-335 and open front door.

5.2.3 DISCONNECT AND ISOLATE electrically, probe circuit wire ANA-WT-LDE-335B-2(-) at terminal block ANA-WT-TB-335-12.

(QC)

5.2.4 QC RECORD lifted wire data on Lift/Land table below.

5.2.5 DISCONNECT AND ISOLATE electrically, circuit wires ANA-WT-LD-335-2 at relay ANA-WT-K-335C. (2 wires) Ref. Dwg. H-14-100990.

(QC)

5.2.6 QC RECORD lifted wire data on Lift/Land table below. LIFT / LAND TABLE

\begin{tabular}{|c|c|c|c|c|c|c|}
\hline WIRE NUMBER & $\begin{array}{l}\text { Step } \\
\text { No. }\end{array}$ & Date & $\begin{array}{l}\text { OC } \\
\text { INITIAL }\end{array}$ & step & DANEE & WITIA \\
\hline ANA-WT $-\mathrm{CDE} \cdot 3.3 .5 \mathrm{~B}-2(-2)$ & 5.2 .3 .3 & & & 5.2 .13 & & \\
\hline ANA-WT: LD $335-2$ & 5.2 .5$. & & & 5.2 .15 & & \\
\hline ANA,$W T-1 D=3.35 .2$. & 5.2 .5$. & & & 5.2 .15 & & \\
\hline
\end{tabular}




\subsection{SETTING THE MTL TRIP AMPLIFIER (Cont.)}

5.2.7 ENERGIZE leak detection relay panel ANA-WT-LDSTA-335. AND ACTIVATE "Alarm Reset" switch ANA-WT-PB-335C.

5.2.8 VERIFY AND RECORD on TABLE 1, initial state of each output set of contacts (Terminal No.'s $10 \& 11$ and $13 \& 14$, Drawing No.H-14-100990) as OPEN or CLOSED with use of volt/ohm meter.

5.2.9 APPLY 1.5 volts dc using $0-10$ volt dc adjustable source to (Item No. 22, Drawing No. H-14-100983) terminals 1 and 4.

5.2.10 ADJUST set point potentiometer on the MTL Trip Amplifier (Item No. 22, Drawing No. H-14-100983) untif it actuates or the output contacts change state from the state recorded above at the applied 1.5 volts dc.

5.2.11 VERIFY AND RECORD On TABLE 1, the state of each set of contacts after adjusting the set point potentiometer. Each contact verified in Step 5.2 .8 should have changed state.

TABLE 1

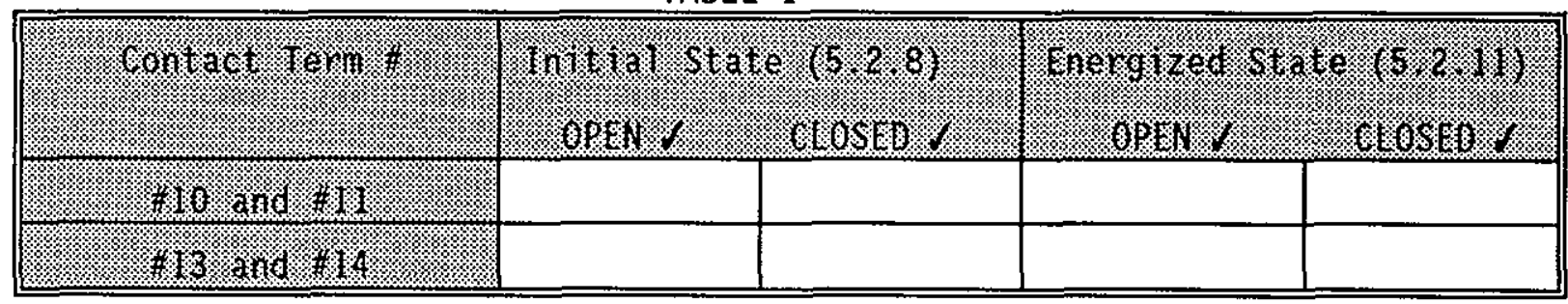

Test Director Initial

\begin{tabular}{|c|c|c|c|c|}
\hline 13. & 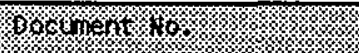 & (2) & 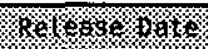 & $6 y=$ \\
\hline orom & 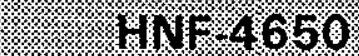 & ; & & 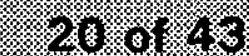 \\
\hline
\end{tabular}




\subsection{SETTING THE MTL TRIP AMPLIFIER (Cont.)}

5.2.12 DEENERGIZE leak detection relay cabinet AND REMOVE adjustable voltage source.

5.2.13 REPLACE probe circuit wire ANA-WT-LDE-335B-2(-) at terminal block ANA-WT-TB-335-12 AND TORQUE termination screw to 7 inch/lbs.

(Qc)

5.2.14 QC RECORD landed wire data on Lift/Land table.

5.2.15 REPLACE BOTH circuit wires ANA-WT-LD-335-2 at relay ANA-WT-K-335C AND TORQUE termination screw to 7 inch/lbs.

(Qc)

5.2.16 QC RECORD landed wire data on Lift/Land table.

5.2.17 CLOSE panel door.

5.2.18 VERIFY Test 5.2 is COMPLETE by.

\begin{tabular}{cc}
\hline Test Director Signature & Date \\
\hline Operations Signature & Date
\end{tabular}

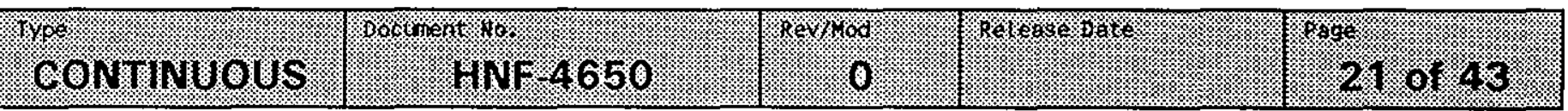




\subsection{B/W LEAK DETECTION RELAY SWITCH TEST}

NOTE - This test verifies the functionality of the $B / W$

intrinsically safe relay. By rotating the selector switch to the "PROBE TEST" position, an internal resistor

simulates a load across the probes and activates the $B / W$ intrinsically safe leak detection relay.

ELECTRICAL TEST EQUIPMENT DATA TABLE

\begin{tabular}{||l|l|l|l|}
\hline \hline TOOL NAME & ID. NUMBER & CAL DUE DATE & INITIAL/DATE \\
\hline & & & \\
\hline & & & \\
\hline & & & \\
\hline
\end{tabular}

5.3.1 LOCATE \& ENSURE ANA-WT-LDSTA-335 disconnect switch ANA-WT-DS-335 (Orawing No. H-14-100990) is in the CLOSED or ON position AND local strobe light alarm is DEACTIVATED.

5.3.2 ROTATE the selector switch ANA-WT-SS-335 to the "PROBE TEST" position, THEN RELEASE allowing spring return to the "Operate" position.

5.3.3 VERIFY local strobe Tight alarm ANA-WT-LDA-335A located on ANA-WT-LDSTA-335 is activated.

\section{Test Director Initial Date}

5.3.4 ROTATE AND HOLD selector switch ANA-WT-SS-335 to the "PROBE TEST" position.

5.3.5 MEASURE AND RECORD the voltage BETWEEN Terminal TB-DC2-67 AND Terminal TB-DC2-66 in Field Terminal Box AN241-WT-TBX-101.

VOLTAGE

\begin{tabular}{|c|c|c|c|c|}
\hline W/ & Wroritent. & & 1) & \\
\hline 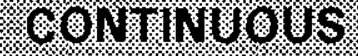 & $(n)=4650$ & (3: & & $3 \% 8 \% 16$ \\
\hline
\end{tabular}




\subsection{B/W LEAK DETECTION RELAY SWITCH TEST (Cont.)}

5.3.6 VERIFY the voltage recorded in Step 5.3 .5 is at a nominal range of " 0 " Volts dc.

$$
\text { Test Director Initial Date }
$$

5.3.7 RELEASE the selector switch ANA-WT-SS-335 from the "PROBE TEST" position. (Switch should return to "OPERATE" position).

5.3.8 LOCATE AND ACTIVATE "ALARM RESET" Switch

ANA-WT-PB-335C.

5.3.9 VERIFY Tocal strobe light alarm in Step 5.3.3 is NOT operating.

$$
\text { Test Director Initial }
$$

Date

5.3.10 MEASURE AND RECORD - voltage BETWEEN Terminal TB-DC2-67 AND Terminal TB-DC2-66 in Field Terminal Box AN241-WT-TBX-101.

VOLTAGE

5.3.11 VERIFY voltage recorded in Step 5.3.10. is at a nominal range of "24" Volts dc.

Test Director Initial

Date

5.3.12 VERIFY Test 5.3 is COMPLETE.

Test Director Signature

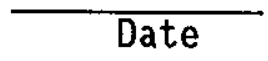

Operations Signature

Date

Gorm




\subsection{LAMP TEST}

NOTE - The "LAMP TEST" push-button ANA-WT-PB-335E is designed to test the strobe light alarm from the field. The following procedure demonstrates how to perform this function.

ELECTRICAL TEST EQUIPMENT DATA TABLE

\begin{tabular}{|l|l|l|l|}
\hline TOOL NAME & ID. NUMBER & CAL DUE DATE & INITIAL/DATE \\
\hline & & & \\
\hline & & & \\
\hline & & & \\
\hline
\end{tabular}

5.4.1 ENSURE ANA-WT-LDSTA-335 disconnect switch ANA-WT-DS-335, drawing reference No. H-14-100990, is in the CLOSED or ON position AND local strobe light alarm is DEACTIVATED.

5.4.2 DEPRESS "LAMP TEST" PUSH BUTTON switch ANA-WT-PB-335E, Drawing No. H-14-100990, and hold.

5.4.3 VERIFY local strobe light alarm ANA-WT-LDA-335A, Drawing No. H-14-100990, is activated.

\section{$\overline{\text { Test Director Initial }}$}

5.4.4 RELEASE "LAMP TEST" PUSH BUTTON switch ANA-WT-PB-335E.

5.4.5 VERIFY local strobe light alarm ANA-WT-LDA-335A is NOT activated.

Test Director Initial

Date

5.4.6 VERIFY Test 5.4 is COMPLETE.

\begin{tabular}{l} 
Test Director Signature \\
\hline Operations Signature
\end{tabular}




\subsection{B/W LEAK DETECTION RELAY LEAK SIMULATION TEST}

NOTE - The $B / W$ leak detection relay leak simulation tests the probe circuit by adding Tiquid to the "TEST RISER".

Adding water to the "TEST RISER" will be detected by the

probe circuit and local alarms and remote signals will be generated. Use of camera will be required to perform

visual verification during this test. (Reference procedure T0-020-265).

ELECTRICAL TEST EQUIPMENT DATA TABLE

\begin{tabular}{||l|l|l|l|}
\hline \hline TOOL NAME & ID. NUMBER & CAL DUE DATE & INITIAL/DATE \\
\hline & & & \\
\hline & & & \\
\hline & & & \\
\hline
\end{tabular}

5.5.1 ENSURE ANA-WT-LDSTA-335 disconnect switch ANA-WT-DS-335, Drawing No. H-14-100990, is in the CLOSED or ON position AND local strobe light al arm is DEACTIVATED.

5.5.2 VERIFY VaTve WT-V-404 is in the "OPERATE" position.

$$
\text { Test Director Initia1 }
$$

5.5.3 LOCATE "TEST RISER" associated with ANA-WT-LDE-335 at valve pit 241-AN-A. (Reference Drawing H-14-100984).

5.5.4 REMOVE cap from "TEST RISER".

5.5.5 POUR "RAW WATER" in "TEST RISER" SLOWLY until al arm activates or water runs out of the "OPERATE PORT" of valve WT-V-404.

5.5.6 VERIFY local strobe light alarm ANA-WT-LDA-335A located on ANA-WT-LDSTA-335 is activated.

$\overline{\text { Test Director Initial }}$

5.5.7 LOCATE AND ACTIVATE "ALARM RESET" Switch ANA-WT-PB-335C located on ANA-WT-LDSTA-335.

5.5.8 VERIFY local strobe light alarm remains activated.

Test Director Initia

\begin{tabular}{|c|c|c|c|c|}
\hline Gorminurous & 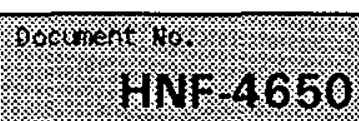 & Tervor & ror & 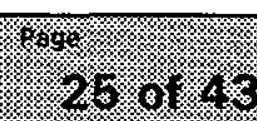 \\
\hline
\end{tabular}




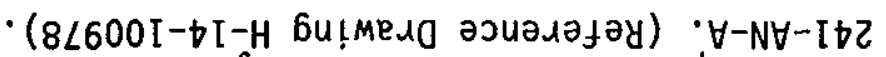

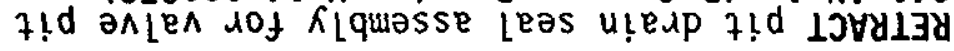

- Кட४46!7

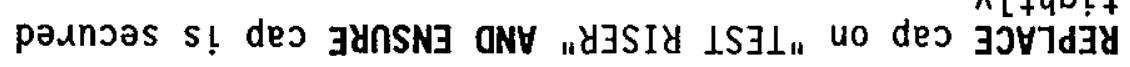
$\angle I \cdot \mathcal{G} \cdot \mathcal{G}$

- pauteup sey $1 ә 7 \mathrm{em}$

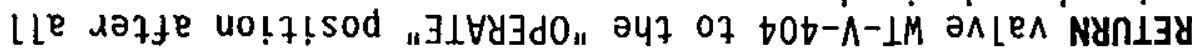

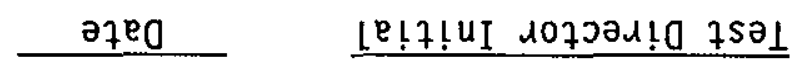

- op s7lon "tz" 10 ә6ued

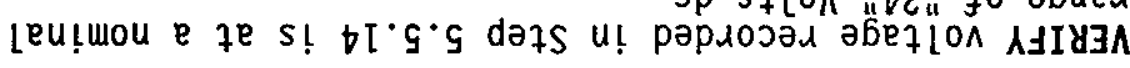
$\mathrm{GI} \cdot \mathrm{q} \cdot \mathrm{G}$

$$
\text { उפ十1701 }
$$

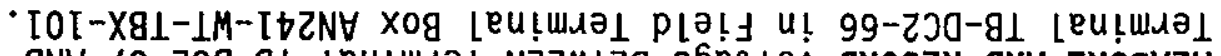

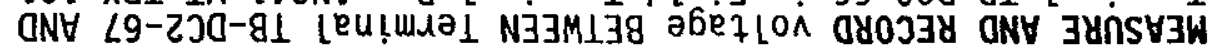

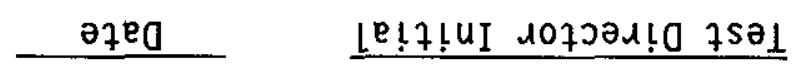

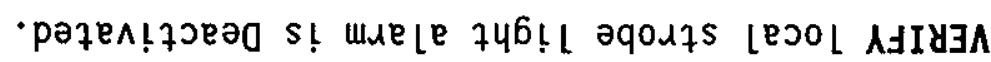

$\varepsilon I \cdot q \cdot s$

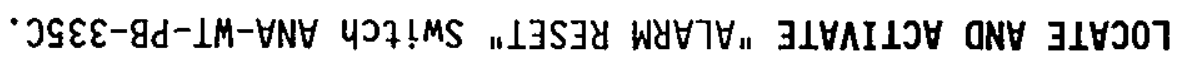
$2 I \cdot g \cdot s$

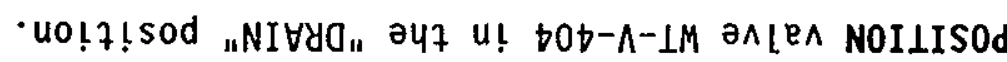

$$
\text { ә7е0 }
$$

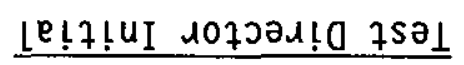

- op s7lon "0" fo abued

Leu!mou e ze s! 6.9.5 dazs u! paprojal a6ezlon $\lambda \leq I 8 \exists \Lambda$ $O I^{\prime} \cdot \mathrm{g} \cdot \mathrm{G}$

$$
\text { ээพ } 170 \Lambda
$$

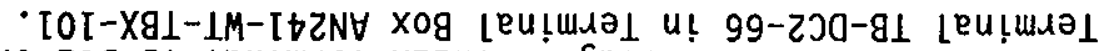

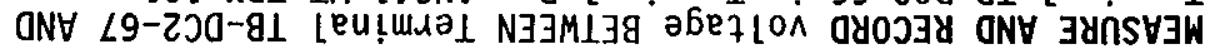

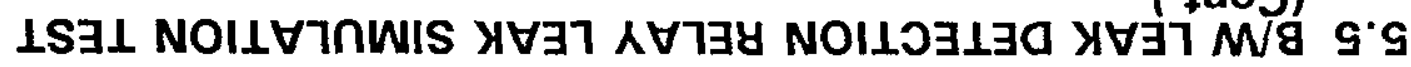




\subsection{B/W LEAK DETECTION RELAY LEAK SIMULATION TEST. (Cont.)}

5.5.19 VERIFY visually NO standing water remains in valve pit 241-AN-A.

Test Director Initial

5.5.20 RESET valve pit 241-AN-A drain seal assembly.

5.5.21 VERIFY Test 5.5 is COMPLETE.

\begin{tabular}{l} 
Test Director Signature \\
\hline Operations Signature
\end{tabular}

\begin{tabular}{c}
\hline Date \\
\hline Date
\end{tabular}




\subsection{MTL FAIL SAFE RELAY SWITCH TEST}

NOTE - The leak detection fail safe relay switch test identifies the functionality of the fail safe testing circuit. The test relay opens a probe circuit wire and activates the MTL Trip Amplifier.

ELECTRICAL TEST EQUIPMENT DATA TABLE

\begin{tabular}{|l|l|l|l|}
\hline TOOL NAME & ID. NUMBER & CAL DUE DATE & INITIAL/DATE \\
\hline & & & \\
\hline & & & \\
\hline & & & \\
\hline
\end{tabular}

5.6.1 ENSURE ANA-WT-LDSTA-335 disconnect switch ANA-WT-DS-335, reference drawing No. $\mathrm{H}-14-100990$, is in the CLOSED or ON position AND Tocal strobe light alarm is DEACTIVATED.

5.6.2 ROTATE selector switch ANA-WT-SS-335 to "FAIL RELAY TEST" position, THEN RELEASE allowing spring return to the "OPERATE" position.

5.6.3 VERIFY local strobe light alarm ANA-WT-LDA-335A, reference No. H-14-100990, is activated.

$$
\text { Test Director Initial }
$$

5.6.4 LOCATE, Field Terminal Box AN241-WT-TBX-101.

(Reference Drawing H-14-100988).

5.6.5 ROTATE AND HOLD selector switch ANA-WT-SS-335 in "FAIL RELAY TEST" position.

5.6.6 MEASURE AND RECORD voltage BETWEEN Terminal TB-DC2-67 AND Terminal TB-DC2-68 in Field Terminal Box AN241-WT-TBX-101.

5.6.7 VERIFY voltage recorded in Step 5.6.6 is at a nominal range of "O" Volts dc.

$$
\overline{\text { Test Director Initial }}
$$


This page cannot be converted.

Please view the native document

for the original page. 


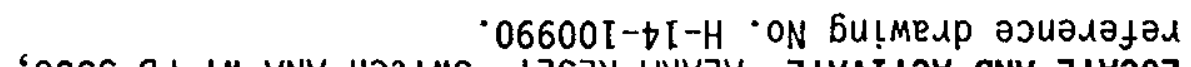

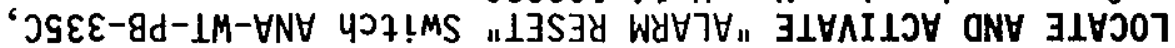

$$
\text { ә7еQ }
$$

-pә7en!7Je s! '06600I-t[-H ON 6u!mesp

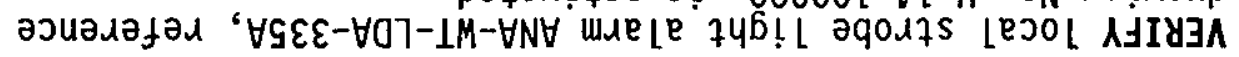
$b \cdot L \cdot G$

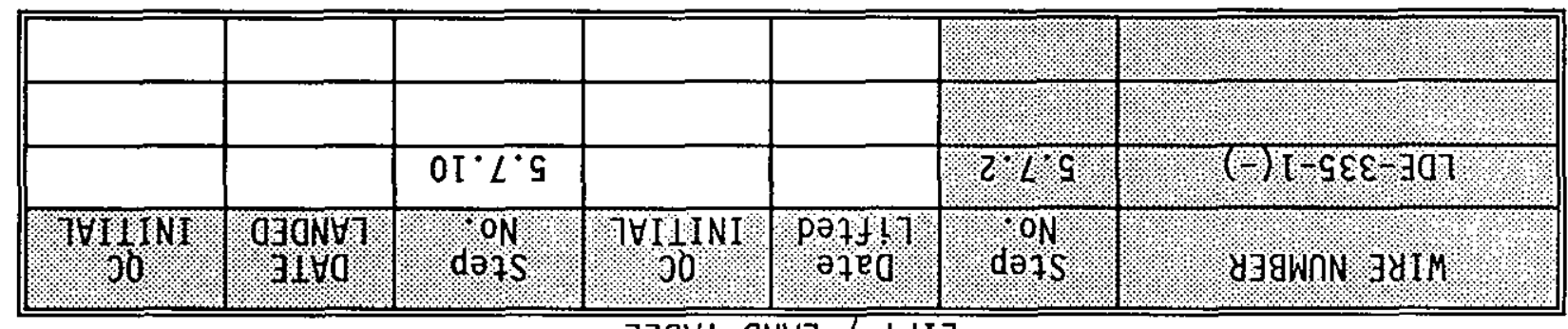

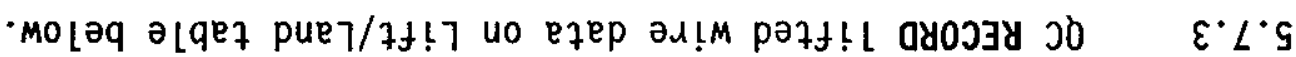

$\cdot(06600[-t[-H$ 6u!mesa әэиәләјәу)

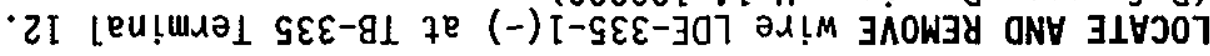

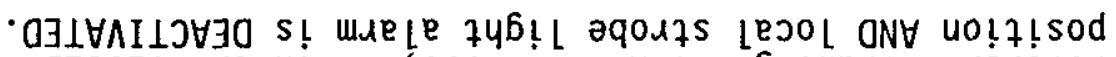

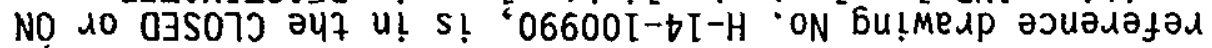

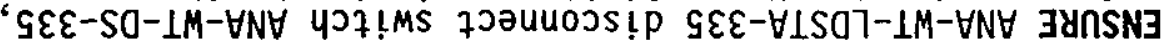

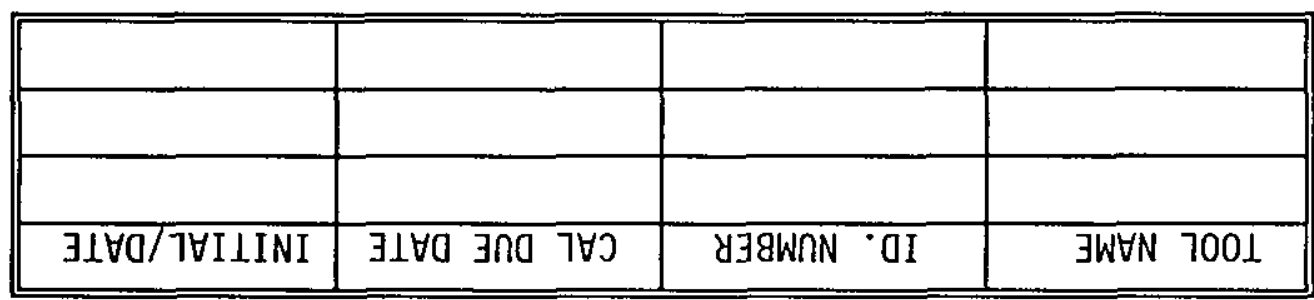

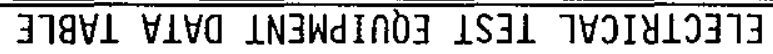

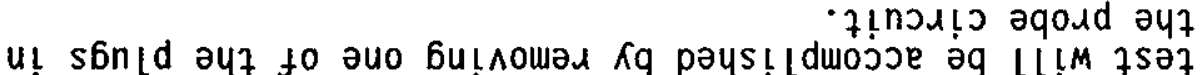

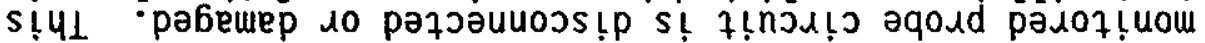

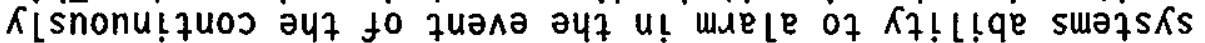

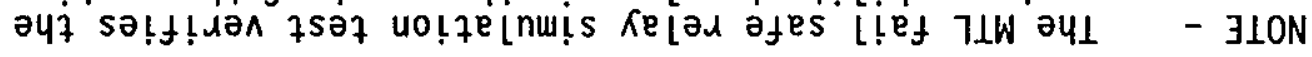




\section{$\exists \fallingdotseq \forall \perp 70 \wedge$}

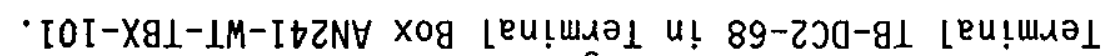

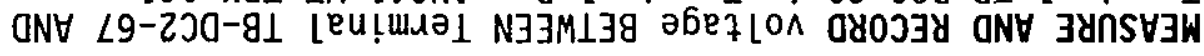
$G[\cdot L \cdot G$

$$
\text { ә7е0 }
$$

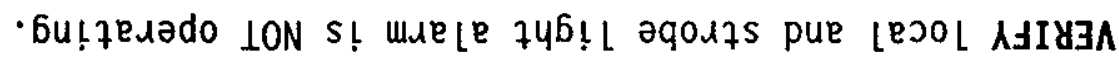
$t[\cdot L \cdot s$

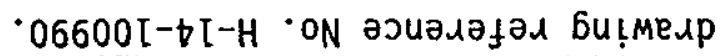

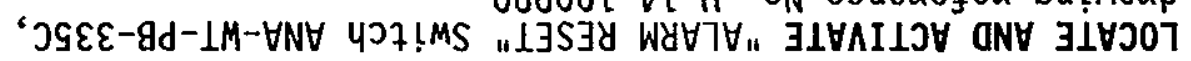
$\varepsilon[\cdot L \cdot \mathcal{G}$

$$
\text { ә7еa } \underline{\text { [e!7! UI 107001!0 7501 }}
$$

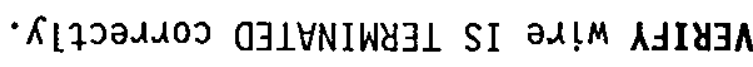

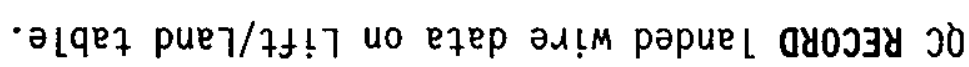

$Z I \cdot L \cdot G$

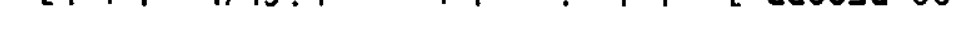

II $\cdot L \cdot G$

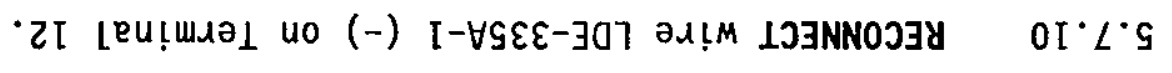

$$
\text { ә7е0 } \quad \text { [e!7! }
$$

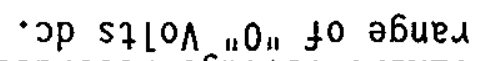

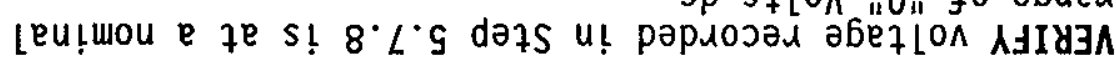

\section{$\exists 9 \forall 170 \wedge$}

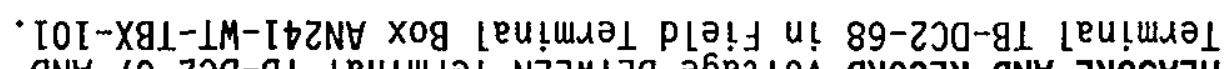

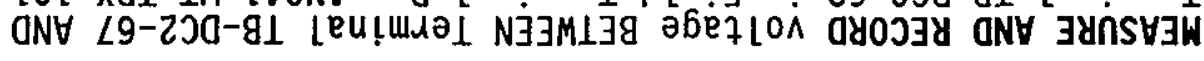

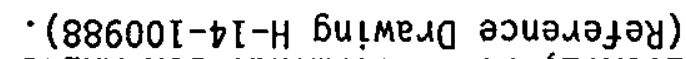

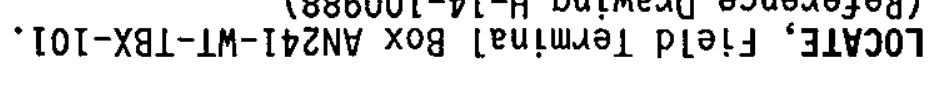

$L \cdot L \cdot G$

$$
\text { ә750 }
$$

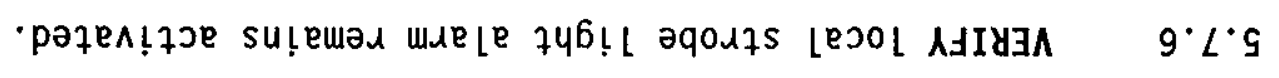

(’) 


\subsection{MTL FAIL SAFE RELAY SIMULATION TEST (Cont.)}

5.7.16 VERIFY voltage recorded in Step 5.7.15 is at a nominal range of "24" Voits dc.

$$
\text { Test Director Initial }
$$

5.7.17 VERIFY Test 5.7 is COMPLETE.

\begin{tabular}{l}
\hline Test Director Signature \\
\hline Operations Signature
\end{tabular}

$\frac{\text { Date }}{\text { Date }}$




\subsection{REMOTE RESET TEST}

NOTE - The remote leak detection relay test is a function that allows the operator to reset the leak detection relay panel from the HMI. For the purposes of this ATP, a signal will be generated from Field Terminal Box AN241-WTTBX-101 to the field device. An insulated temporary switch with jumper wires will be needed for this procedure.

ELECTRICAL TEST EQUIPMENT DATA TABLE

\begin{tabular}{|l|l|l|l|}
\hline TOOL NAME & ID. NUMBER & CAL DUE DATE & INITIAL/DATE \\
\hline & & & \\
\hline & & & \\
\hline & & & \\
\hline
\end{tabular}

5.8.1 ENSURE ANA-WT-LDSTA-335 disconnect switch ANA-WT-DS-335, reference drawing No. H-14-100990, is in the Open or OFF position, AND local strobe light alarm is deactivated.

5.8.2 WIRE a temporary switch, S-1, BETWEEN Terminal TB-DC4-51 AND TB-DC2-63 in Terminat BoX AN241-WT-TBX-101.

5.8.3 QC VERIFY temporary switch installed.

$$
\text { QC Initial Date }
$$

5.8.4 VERIFY AND ENSURE temporary switch is in the OPEN or OFF position

$$
\text { Test Director Initial Date }
$$

5.8.5 ENSURE ANA-WT-LDSTA-335 disconnect switch ANA-WT-DS-335, is in the CLOSED or ON position. (Reference drawing No. H-14-100990) AND local strobe light alarm is DEACTIVATED.

5.8.6 ROTATE selector switch ANA-WT-SS-335 to the "PROBE TEST" position, THEN RELEASE allowing spring return to the "OPERATE" position.

5.8.7 VERIFY local strobe 1 ight alarm ANA-WT-LDA-335A, reference drawing No. H-14-100990, is activated.

\begin{tabular}{|c|c|c|c|c|}
\hline 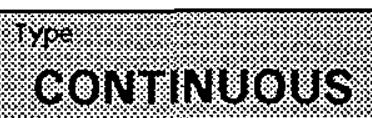 & ring & (3) & 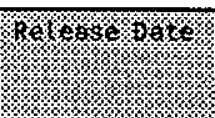 & m. \\
\hline
\end{tabular}

$\overline{\text { Test Director Initial }}$




\subsection{REMOTE RESET TEST Cont.)}

5.8.8 MEASURE AND RECORD voltage BETWEEN Terminal TB-DC4-51 AND Terminal TB-DC2-63 in TerminaT Box AN241-WT-TBX-101.

VOLTAGE

5.8.9 VERIFY voltage recorded in Step 5.8 .8 is at a nominal range of "24" Volts dc.

\section{Test Director Initial}

5.8.10 Momentarily CLOSE then OPEN temporary switch, S-1, installed in Step 5.8.2.

5.8.11 VERIFY local strobe light alarm ANA-WT-LDA-335A, reference drawing No. H-14-100990, is deactivated.

$$
\overline{\text { Test Director Initial }} \overline{\text { Date }}
$$

5.8.12 ENSURE ANA-WT-LDSTA-335 disconnect switch ANA-WT-DS-335, is in the Open or OFF position, AND local strobe light alarm is deactivated.

5.8.13 REMOVE temporary switch, S-1, BETWEEN Terminal TB-DC4-51 AND TB-DC2-63 in Terminal Box AN241-WT-TBX-101.

(QC)

5.8.14 QC VERIFY temporary switch removed.

QC Initial

5.8.15 VERIFY Test 5.8 is COMPLETE.

\begin{tabular}{cc}
\hline Test Director Signature & Date \\
\hline Operations Signature & Date
\end{tabular}




\subsection{REMOTE TRIP AMPLIFIERIVOLTAGE RELAY TEST}

NOTE - The remote leak detection relay test is a function that allows the operator to test the trip amplifier voltage relay from the HMI display. For the purposes of this ATP, a signal will be generated from the Field Terminal Box AN241-WT-TBX-101. An insulated temporary switch with jumper wires will be needed for this procedure.

ELECTRICAL TEST EQUIPMENT DATA TABLE

\begin{tabular}{|l|l|l|l|}
\hline TOOL NAME & ID. NUMBER & CAL DUE DATE & INITIAL/DATE \\
\hline & & & \\
\hline & & & \\
\hline & & & \\
\hline
\end{tabular}

5.9.1 ENSURE ANA-WT-LDSTA-335 disconnect switch ANA-WT-DS-335, reference drawing No. H-14-100990, is in the OPEN or OFF position, AND local strobe light alarm is deactivated.

5.9.2 WIRE a temporary switch, S-1, BETWEEN Terminal TB-DC4-51 AND TB-OC2-65 in Terminal Box AN241-WT-TBX-101.

5.9.3 QC VERIFY temporary switch installed.
QC Initia]
Date

5.9.4 VERIFY temporary switch is in the OPEN or OFF position.

Test Director Initial

\section{Date}

5.9.5 ENSURE ANA-WT-LDSTA-335 disconnect switch ANA-WT-DS-335, reference drawing No. $\mathrm{H}-14-100990$, is in the CLOSED or ON position AND local strobe light alarm is DEACTIVATED.

5.9.6 MEASURE AND RECORD voltage BETWEEN Terminal TB-DC4-51 AND Terminal TB-DC2-65 in Terminal Box AN241-WT-TBX-101.

VOLTAGE

5.9.7 VERIFY voltage recorded in Step 5.9.6 is at a nominal range of "24" Volts dc.

$\overline{\text { Test Director Initial }}$

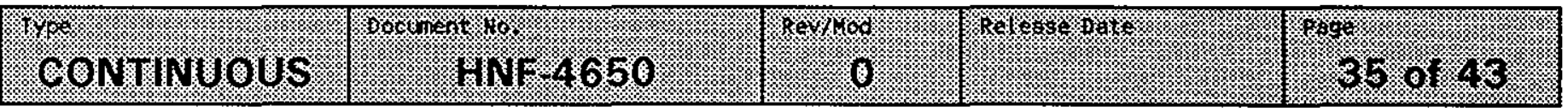




\subsection{REMOTE TRIP AMPLIFIERIVOLTAGE RELAY TEST}

\subsubsection{Momentarily CLOSE THEN OPEN temporary switch, S-1, installed in Step 5.9.2.}

5.9.9 VERIFY local strobe light alarm ANA-WT-LDA-335A, reference drawing No. H-14-100990, is activated.

$$
\text { Test Director Initial }
$$

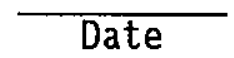

5.9.10 LOCATE AND ACTIVATE "ALARM RESET" Switch ANA-WT-PB-335C, reference drawing No. H-14-100990.

5.9.11 VERIFY local strobe light alarm ANA-WT-LDA-335A is deactivated.

$$
\text { Test Director Initial }
$$$$
\overline{\text { Date }}
$$

5.9.12 ENSURE ANA-WT-LDSTA-335 disconnect switch ANA-WT-DS-335, reference drawing No. H-14-100990, is in the OPEN or OFF position, AND local strobe light alarm is deactivated.

5.9.13 REMOVE temporary switch, S-1, BETWEEN Terminal TB-DC4-51 AND TB-DC2-65 in Terminal Box AN241-WT-TBX-101.

5.9.14 QC VERIFY temporary switch removed.

QC Initial $\quad$ Date

5.9.15 VERIFY Test 5.9 is COMPLETE.

\begin{tabular}{cc}
\hline Test Director Signature & Date \\
\hline Operations Signature &
\end{tabular}




\subsection{REMOTE LEAK DETECTION RELAY TEST. (Pit Leak Detection Probe Test)}

NOTE - The remote leak detection relay test is a function that allows the operator to test the leak detection relay from the HMI display. For the purposes of this ATP, a signal will be generated from the Field Terminal Box AN241-WTTBX-101. An insulated temporary switch with jumper wires will be needed for this procedure.

ELECTRICAL TEST EQUIPMENT DATA TABLE

\begin{tabular}{|l|l|l|l||}
\hline TOOL NAME & ID. NUMBER & CAL DUE DATE & INITIAL/DATE \\
\hline & & & \\
\hline & & & \\
\hline & & & \\
\hline
\end{tabular}

5.10.1 ENSURE ANA-WT-LDSTA-335 disconnect switch ANA-WT-DS-335, is in the OPEN or OFF position, AND local strobe light alarm is deactivated. (Reference drawing No. H-14-100990).

5.10.2 WIRE a temporary switch, S-1, BETWEEN Terminal TB-DC4-5I AND TB-DC2-64 in Terminat BoX AN241-WT-TBX-101.

5.10.3 QC VERIFY temporary switch installed.

$$
\text { QC Initial Date }
$$

5.10.4 VERIFY temporary switch is in the OPEN or OFF position.

$$
\text { Test Director Initial }
$$

5.10.5 ENSURE ANA-WT-LDSTA-335 disconnect switch ANA-WT-DS-335, reference drawing No. H-14-100990, is in the CLOSED or ON position AND local strobe light alarm is DEACTIVATED.

5.10.6 MEASURE AND RECORD voltage BETWEEN Terminal TB-DC4-51 AND Terminal TB-DC2-64 in Terminal Box AN241-WT-TBX-101.

VOLTAGE

5.10.7 VERIFY voltage recorded in Step 5.10.6 is at a nominal range of "24" Volts dc.

$$
\overline{\text { Test Director Initial }} \overline{\text { Date }}
$$




\subsection{REMOTE LEAK DETECTION RELAY TEST (Cont.)}

5.10.8 Momentarily CLOSE THEN OPEN temporary switch, S-1, installed in Step 5,10.2.

5.10.9 VERIFY local strobe light alarm ANA-WT-LDA-335A, reference drawing No. H-14-100990, is activated.

$$
\text { Test Director Initial Date }
$$

5.10.10 LOCATE AND ACTIVATE "ALARM RESET" Switch ANA-WT-PB-335C. (Reference drawing No. H-14-100990).

5.10.11 VERIFY Tocal strobe light alarm ANA-WT-LDA-335A is deactivated.

$$
\overline{\text { Test Director Initial }}
$$

5.10.12 ENSURE ANA-WT-LDSTA-335 disconnect switch ANA-WT-DS-335, is in the OPEN or OFF position, AND Tocal strobe light alarm is deactivated. (Reference drawing No. H-14-100990).

5.10.13 REMOVE temporary switch, S-1, BETWEEN Terminal TB-DC4-51 AND TB-DC2-64 in Terminal Box AN241-WT-TBX-101.

5.10.14 QC VERIFY temporary switch removed.

$\overline{\text { QC Initial }}$

5.10.15 VERIFY Test 5.10 is COMPLETE.

\begin{tabular}{l}
\hline Test Director Signature \\
\hline Operations Signature
\end{tabular}

\begin{tabular}{c}
\hline Date \\
\hline Date
\end{tabular}




\section{ATP PERFORMANCE LOG}

This page may be reproduced as necessary.

Page of

\begin{tabular}{|c|c|c|}
\hline ATP PERFORMANCE EVENT & DATE: & IHIIAS \\
\hline . & & \\
\hline & & \\
\hline & & \\
\hline & & \\
\hline & & \\
\hline & & \\
\hline & & \\
\hline & & \\
\hline & & \\
\hline & & \\
\hline & & \\
\hline & & \\
\hline & & \\
\hline & & \\
\hline & & \\
\hline & & \\
\hline & & \\
\hline & & \\
\hline & & \\
\hline & & \\
\hline & & \\
\hline
\end{tabular}




\section{ATP EXCEPTION LOG}

This page may be reproduced as necessary.

Page of

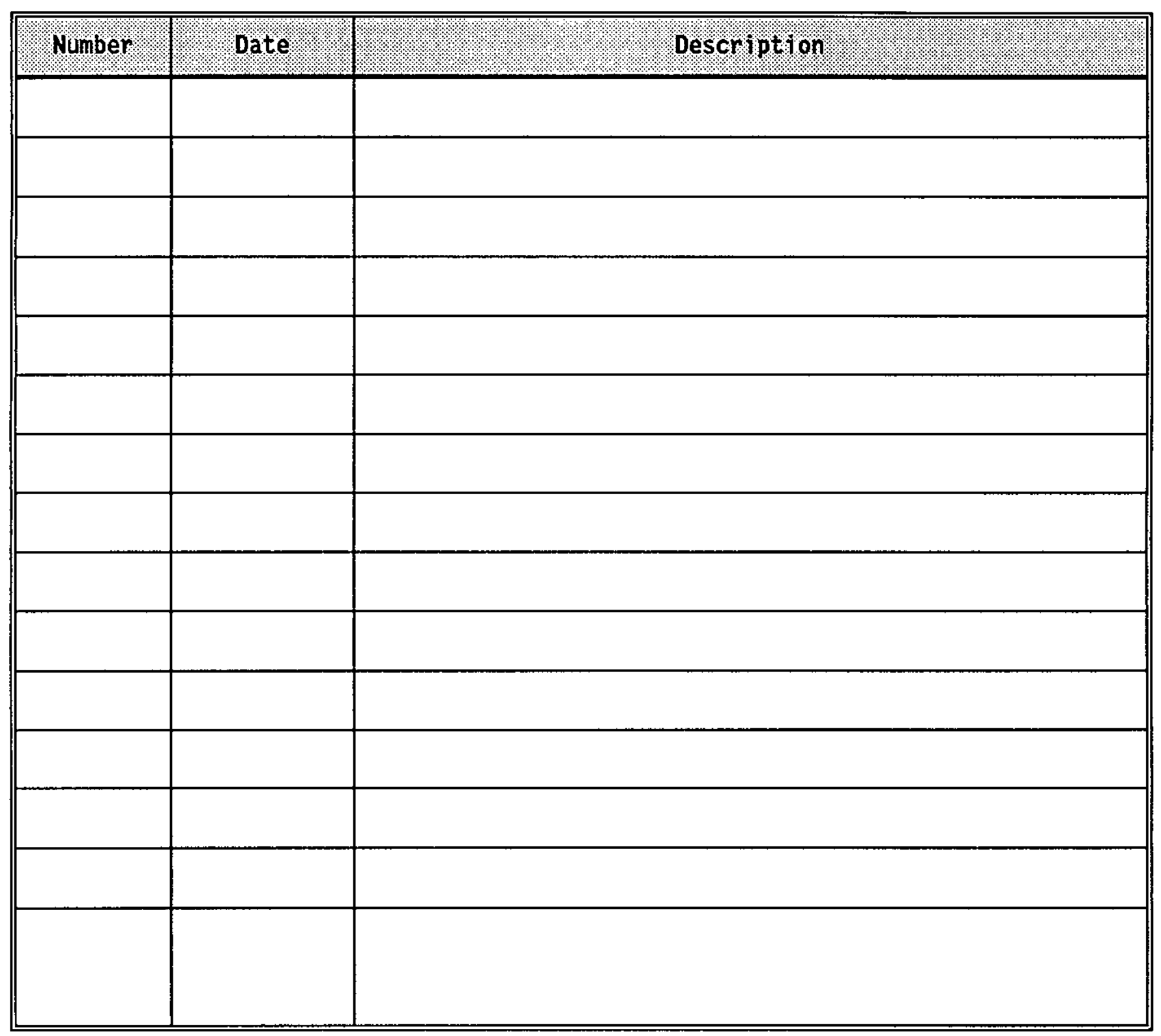




\section{ATP EXCEPTION RECORD}

This page may be reproduced as necessary.

$$
\text { Page }
$$
of

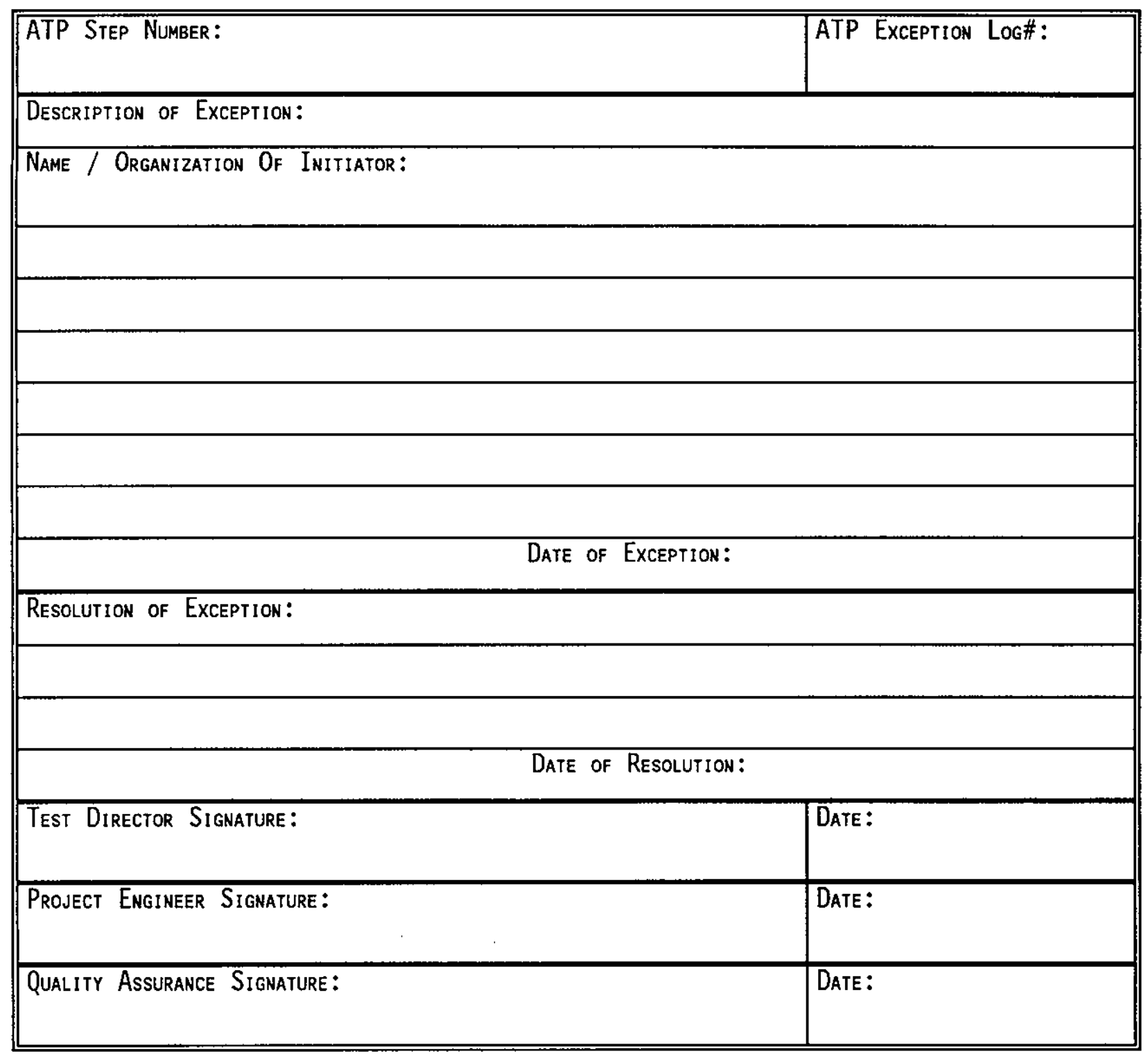




\section{PROCEDURE SIGNATURE SHEET}

PRINT NAME

SIGNATURE
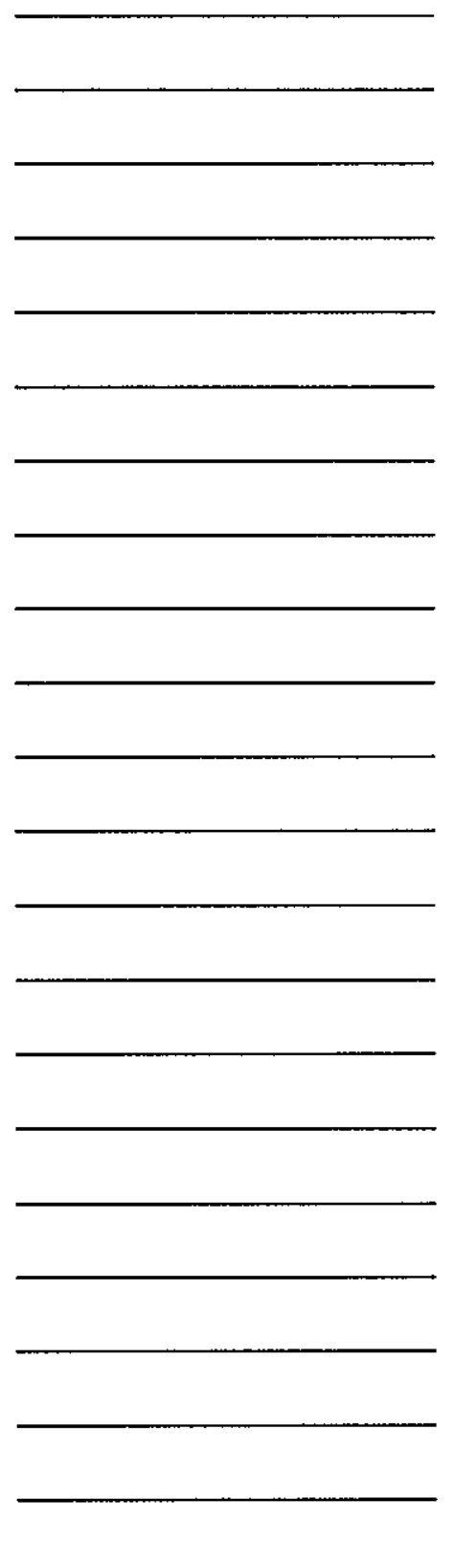

INITIALS

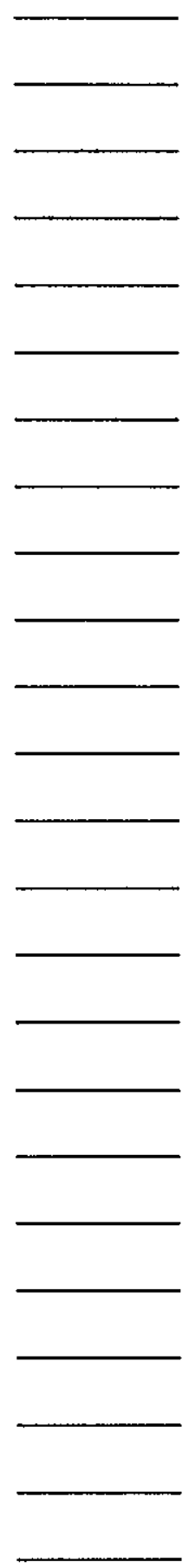




\section{PROCEDURE HISTORY SIGNATURE SHEET}

\begin{tabular}{|c|c|c|c|c|}
\hline Mpra & 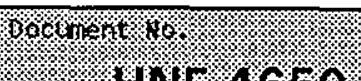 & 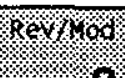 & 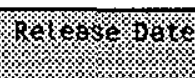 & 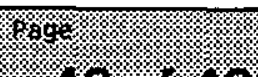 \\
\hline - & : & 0 & & ; \\
\hline
\end{tabular}

